\title{
The Movement of CONSUMER Protection IN THE EUROPEAN COMMUNITY: A VITAL LINK IN THE ESTABLISHMENT OF FREE TRADE AND A PARADIGM FOR NORTH AMERICA
}

"The first duty of law is to keep sound the society it serves. Sanitary laws, pure food laws, and laws determining conditions of labor which individuals are powerless to determine for themselves are intimate parts of the very business of justice and legal efficiency."

\section{INTRODUCTION}

Through the implementation of consumer protection laws, a nation seeks to protect its citizens from the dangers of consuming hazardous products that fail to comply with national health and safety standards. However, because consumer protection laws vary greatly between nations, ${ }^{2}$ a product that complies with the health and safety standards of one nation may fail to meet the standards of another country and thereby be prohibited from sale to consumers within that nation. Therefore, free trade and the protection of consumers are often conflicting objectives. ${ }^{3}$ While the goal of free trade is to eradicate barriers to the free flow of goods between nations, a nation often desires to obstruct the flow of goods that endanger the health and safety of consumers. Consequently, when countries with differing standards become trading partners in a free trade agreement, their varying consumer protection laws may hinder free trade. Balancing the goal of implementing free trade with the goal of protecting consumers has been an onerous task for countries who engage in free trade agreements. Thus, the critical question concerns how a nation reconciles its commitment to open borders with its desire to protect consumers through laws which tend to restrict trade and which vary in content and degree among trading partners.

The creation of free trading blocs such as the European Community $(\mathrm{EC})^{4}$ and, most recently, the North American Free Trade Agreement (NAFTA), make cross-border trade crucial to the world economy. However, varying consumer protection laws have been viewed as impediments to free

1. President Woodrow Wilson, Inaugural Address (March 4, 1913), in 27 PAPERS OF WOODROW WILSON 148, 151 (Arthur S. Link ed., 1978).

2. Sverre Roed Larsen, Organisation for Economic Co-operation and Development, Product Safety, Trade Barriers and Protection of Consumers, in INTERNATIONAL TRADE AND THE CONSUMER, REPORT ON THE 1984 OECD SYMPOSIUM 177, 177 (OECD 1986).

3. Id.

4. The European Community, previously referred to as the European Economic Community (EEC), is now referred to as the "EC" pursuant to the Treaty on European Union art. G. 
cross-border trade, making the synthesis of laws among trading partners imperative. For example, prior to the passage of NAFTA by the United States' House of Representatives on November 17, 1993, many consumer advocate groups in the United States staunchly opposed the agreement on the premise that a free trading relationship with Mexico would jeopardize consumer protection in the United States. ${ }^{5}$ Specifically, critics contended that NAFTA would enable Mexico to challenge, and ultimately to eliminate, consumer protection laws in the United States as non-tariff barriers to trade ${ }^{6}$ which violate the free trade agreement. Additionally, opponents maintained that NAFTA would enable Mexico to flood the market in the United States with products that imperil public health and safety. Thus, critics maintained that, to comply with NAFTA, the United States would be compelled to eradicate consumer protection laws that impede the free movement of goods in North America and would thereby diminish the protection afforded to consumers.

Similar to the controversy surrounding NAFTA, the nations of the EC have been compelled over the past two decades to confront and to resolve the conflicting goals of implementing cross-border trade and preserving consumer protection. Specifically, the varying national health and safety standards of the twelve EC Member States, which afford consumers a disparate level of protection, are often viewed as non-tariff barriers to trade which violate the EC Treaty, ${ }^{7}$ hinder the establishment of free intracommunity trade, and threaten the Community's ability to realize a single European market. ${ }^{8}$ Through the harmonization of national consumer protection laws and the creation of Community-wide health and safety standards, the EC has attempted to protect the public health while eradicating these non-tariff barriers to trade. Likewise, as Canada, Mexico, and the United States embark upon the creation of a single North American market through NAFTA, they, too, will be confronted with the challenge of

5. Public Citizen, Citizens Trade Campaign, and the National Farmers Union were among the consumer groups opposed to NAFTA. See News Conference with Labor, Environmental, Consumer Groups in Response to the NAFTA Accord, Federal News Service, Aug. 13, 1993, available in LEXIS, INTLAW Library, NAFTA File.

6. A non-tariff or technical barrier to trade is an obstruction, other than a tariff, to the free movement of goods between nations. For example, a producer faces a non-tariff or technical barrier to trade when he wants to sell his product in the nation of a trading partner but has to modify it to comply with standards or legal regulations or has to submit it to a testing or certification process. EC Commentaries: Standardisation \$ 1, Coopers \& Lybrand, Apr. 21, 1994, available in LEXIS, INTLAW Library, EURSCP File.

7. TREATY Establishing THE EUROPEAN ECONOMIC COMMUNITY (as amended by Subsequent Treaties) Rome, March 25, 1957, art. 30 [hereinafter EC TREATY].

8. George Argiros, Consumer Safety and the Single European Market: Some Observationsand Proposals, 1 LEGAL. ISSUES OF EUROPEAN INTEGRATION 139, 144 (1990) 
eliminating non-tariff barriers to trade while still maintaining appropriate mechanisms to protect the public health. Like the EC, North America may find the harmonization of national consumer protection laws necessary to facilitate free trade while affording consumers a satisfactory level of protection. Consequently, the movement of consumer protection in the EC which accompanied the Community's endeavor to establish a single European market is a paradigm for North America as it seeks to eradicate barriers to trade and to implement a single market without undermining the protection afforded to consumers.

The developing area of consumer protection as it relates to multilateral trade is of paramount importance to several groups. First, it is important to governments and policy-makers because the ability to harmonize consumer protection laws impacts whether a free trade agreement between nations can be successfully implemented. ${ }^{9}$ Second, it is important to businesspeople because, as they place their products in international markets, a different consumer protection law in a new market may demand a modification of the product, ban the product from the marketplace altogether, or expose the company to greater liability than that to which it is accustomed in domestic markets. ${ }^{10}$ Finally, the developing area of consumer protection is important to consumers whose expectations of product safety and whose rights to legal redress will be impacted directly by the consumer protection laws of trading partners.

This Comment addresses the growing importance of consumer protection law to multilateral free trade as exemplified in the European Community's efforts to implement a single European market and will suggest what North America can learn from the EC experience as it embarks upon the implementation of NAFTA. Part II explores the inherent conflict between free trade and consumer protection. Part III describes the movement in the EC toward the harmonization and standardization of consumer protection laws in order to facilitate trade between Member States. Part IV addresses the importance of consumer protection laws to the successful implementation of NAFTA. Finally, Part V illustrates what North America can learn from the movement of consumer protection in the EC.

9. See Jacques Nusbaumer, Organisation for Economic Co-operation and Development, The Use of Product Standards in International Trade, in INTERNATIONAL TRADE AND THE CONSUMER, REPORT ON THE 1984 OECD SYMPOSIUM 212, 212 (OECD 1986).

10. See, e.g., Louise G. Trubek, Consumer Law and Policy in the European Community: An American Perspective, 3 Journal of Products LaW 101, $110-11$ (1984). 


\section{The Conflicting Goals of Free Trade AND CONSUMER PROTECTION}

Through the creation of national health and safety standards, a nation employs consumer protection laws to shield private consumers from the dangers of consuming hazardous products" which fail to comply with product standards. ${ }^{12}$ For example, prior to the sale of a drug in the United States, a manufacturer must receive approval from the Federal Food and Drug Administration (FDA). However, when the United States enters into a free trading relationship with another nation which has conflicting, and perhaps more lenient, product safety standards, the regulation exercised by the FDA may be viewed by the trading partner as an obstruction to free trade, which requires that "all commodities can be freely imported and exported without special taxes or restrictions being levied."13 Consequently, while "common standards indeed can and do facilitate trade ... divergent standards in different countries rather hamper it." ${ }^{14}$

Free trade mandates the elimination of barriers to the free movement of goods between nations. ${ }^{15}$ In forming the EC, the twelve Member States resolved to establish an "internal market ... an area without internal frontiers in which the free movement of goods, persons, services and capital is ensured."16 Likewise, with the passage of NAFTA, the United States, Canada, and Mexico agreed to "eliminate barriers to trade in, and facilitate the cross border movement of, goods and services between the territories of the Parties." 17 Therefore, the common objective of free trade agreements is to facilitate the sale of foreign goods in domestic markets through the elimination of both tariff and non-tariff barriers to trade. The elimination of tariffs is the catalyst to the implementation of free trade; however, "[t]hese days, trade agreements don't just involve tariffs but revolve around so-called 'non-tariff trade barriers." ${ }^{\prime 18}$ Domestic health and safety

11. Guy Stanley, The Third World Tackles Consumer Protection, BuSINESS AND SOCIETY REVIEW, June 22, 1987, at 31 .

12. See, e.g., Brian W. HaRvey and Deborah L. ParRy, The LAW of Consumer Protection and FaIR TRAding (4th ed. 1992).

13. BLACK'S LAW DiCTIONARY 666 (6th ed. 1990).

14. Nusbaumer, supra note 9.

15. Barriers to trade include both tariff and non-tariff barriers. Specifically, barriers to trade include import and export tariffs and technical barriers to trade in the form of national regulations.

16. EC TREATY art. 8a. Article 8a was added by the Single European Act in 1986.

17. North American Free Trade Agreement U.S.-Mex.-Can., art. 102, available in LEXIS, INTLAW Library, NAFTA File [hereinafter NAFTA].

18. Joan Claybrook, Fast Track Can Be Hazardous to Your Health, THE Washington POST, May 17, 1991, at A25. 
standards, depending on their purpose and construction, can constitute nontariff barriers to trade which may be challenged by a trading partner and eradicated as violative of a free trade agreement. ${ }^{19}$ Consequently, as domestic markets welcome foreign goods through a free trade agreement, the protection afforded to consumers may be lessened or eliminated altogether.

Although restrictive of free trade, consumer protection laws are beneficial to society and are often viewed as imperative for the public welfare. The sacrifice of consumer protection laws to the interests of free trade will heighten the vulnerability of consumers to the hazards of goods which are not required to meet certain levels of health and safety. Therefore,

[u]ninhibited efforts to increase free trade will give the consumer a wider range of products and services at reasonable prices. But what in the short term may seem to be an economic gain for the consumer may also in certain cases result in both damage to health and economic loss over a longer period of time. ${ }^{20}$

Moreover, in both the EC and in North America, a disregard for the protection of the public health and safety in order to facilitate trade constitutes a violation of both free trade agreements which mandate a process of continuous improvement in living standards in the respective communities. $^{21}$ Consequently, there is an inherent conflict between the free movement of goods and consumer protection: while the health and safety of citizens is of paramount importance, national consumer protection laws which prohibit the sale of goods that fail to meet safety requirements can constitute non-tariff barriers to trade which violate free trade agreements. Therefore, "it would be an illusion to assume that the further development of the physical protection of the consumer and additional reductions in trade barriers can occur simultaneously without conflict." ${ }^{\text {22 }}$

The movement of consumer protection in the EC that has accompanied

19. Id.

20. Larsen, supra note 2, at 179.

21. NAFTA provides that the United States, Canada, and Mexico must strive to "improve working conditions and living standards in their respective territories . . preserve the flexibility to safeguard the public welfare." NAFTA, supra note 17, pmbl. Similarly, the EC Treaty provides for the "'constant improvement' of living and working conditions and the promotion of 'a harmonious development of economic activities, a continuous and balanced expansion, an increase in stability and an accelerated raising of the standard of living." EC Commentaries: Consumer Policy § 2, Coopers \& Lybrand, Sept. 22, 1994, available in LEXIS, INTLAW Library, EURSCP File.

22. Larsen, supra note 2, at 179. 
the creation of a single European market illustrates the critical balance between the conflicting goals of consumer protection and free trade. The EC experience demonstrates that, "' $[t]$ he existence of different and divergent regulations risks creating new barriers to the free circulation of goods as soon as safety requirements vary from one country to another and, as a consequence, risks becoming an obstacle to completion of the Internal Market by 1992.'"23 In fact, "there are great variations from country to country and region to region." ${ }^{24}$ The European Community's struggle to establish a single internal market while balancing the national and Community interests in protecting consumers provides a useful model for North America as it attempts to balance the need for consumer protection with the commitment to open borders.

\section{THE MOVEMENT OF CONSUMER PROTECTION IN THE EUROPEAN COMMUNITY}

The European Community originated in 1957 with the Treaty of Rome and currently has twelve members: Belgium, Denmark, France, Germany, Greece, Ireland, Italy, Luxembourg, the Netherlands, Portugal, Spain, and the United Kingdom. ${ }^{25}$ As provided in the Treaty of Rome,

[t]he Community shall have as its task, by establishing a common market and progressively approximating the economic policies of Member States, to promote throughout the Community a harmonious development of economic activities, a continuous and balanced expansion, an increase in stability, an accelerated raising of the standard of living and closer relations between the States belonging to it. ${ }^{26}$

Further, as delineated in the Single European Act, ${ }^{27}$ the EC will fully implement a "completely free market."128 The free movement of goods is one of the most fundamental aspects in the establishment of a common

23. Argiros, supra note 8, at 144.

24. Larsen, supra note 2, at 177.

25. See P.S.R.F. MATHIJSEN, A GUIDE TO EUROPEAN COMMUNITY LAW (Sth ed. 1990).

26. EC TREATY art. 2.

27. The Single European Act was passed on February 28, 1986 and entered into force in July, 1987 as an amendment to the original EEC Treaty of Rome. 1987 O.J. (L169) 1. See also 1992: ONE EUROPEAN MARKET? (Roland Bieber et al. eds., 1992).

28. Mathijsen, supra note 25, at 13. 
market. ${ }^{29}$ To ensure the free movement of goods among Member States, the EC Treaty provides that, "[q]uantitative restrictions on imports and all measures having equivalent effect shall, without prejudice to the following provisions, be prohibited between Member States." ${ }^{30}$ However, this "shall not preclude prohibitions or restrictions on imports, exports or goods in transit justified on grounds of . . . the protection of health and life of humans ... [s] [uch prohibitions or restrictions shall not, however, constitute a means of arbitrary discrimination or a disguised restriction on trade between Member States." ${ }^{13}$ Therefore, the establishment of a single European market requires Member States to eradicate barriers to trade. which are not intended to, nor effective in, protecting the public health.

In eliminating barriers to intracommunity free trade, the EC has determined that "[t]he health and safety of consumers must not be put in danger by the opening up of frontiers. ${ }^{32}$ Currently, an estimated 15,000 to 30,000 deaths within the EC are caused by product-related accidents annually. ${ }^{33}$ Further, approximately forty million people are injured each year, costing the Community in excess of thirty billion European Currency Units (ECU) ${ }^{34}$ in hospitalization and insurance annually. ${ }^{35}$ Many of these accidents are caused by dangerous products such as contaminated food products, hazardous parts, and drugs. ${ }^{36}$ Thus, consumer protection within the Community has become a necessity due to the dangers consumers face within the common market. ${ }^{37}$ Recognizing this need for consumer protection, the Single European Act "calls on the European Community to ensure, in its initiatives linked to the completion of the Internal Market, that consumers are granted a 'high' level of protection." ${ }^{138}$ Additionally, the EC has found that "[s]ome of the main obstacles to genuine free trade among

29. Harry L. Clark, The Free Movement of Goods and Regulation for Public Health and Consumer Protection in the EEC: The West German "Beer Purity" Case, 28 VA. J. INT'L L. 753, 757-58 (1988).

30. EC TREATY art. 30.

31. EC TREATY art. 36 (emphasis added).

32. Monique Goyens, Consumer Protection in a Single European Market: What Challenge for the EC Agenda?, 29 COMMON MKT. L. REV. 71, 82 (1992).

33. Argiros, supra note 8, at 139.

34. As of January 14, 1994, an ECU was equal in value to $\$ 1.11$.

35. Argiros, supra note 8, at 139.

36. Id.

37. Id.

38. Coopers \& Lybrand, supra note $21, \S 1$. Article $100 \mathrm{~A}$ was added by the Single European Act in 1987 and provides that, "[t]he Commission, in its proposals envisaged in paragraph I concerning health, safety, environmental protection and consumer protection, will take as a base a high level of protection." Single European Act, Feb. 28, 19861987 O.J. (L169) 1. 
the Member States are the differences in standards and legal requirements of manufactured goods. ${ }^{139}$ Therefore, although

[t]he EC was initially set up to foster economic integration . . . [i]ts primary concern has been to ban all intra-Community tariffs and gradually to reduce all other obstacles to the free flow of goods, services and factors of production within Europe ... [t]he Community's concern with consumer protection stems in part from its desire to implement the open borders policy: if the several national consumer protection laws varied substantially, this lack of legal uniformity could hamper the economic integration process. $^{40}$

The disharmony between the Member States' national consumer protection laws has impeded, and continues to hinder, the establishment of a European common market in which consumers are afforded a high level of protection.

\section{A. National Consumer Protection Law}

When the twelve EC Member States united to form the European Community, each nation afforded varying levels of protection to consumers. ${ }^{41}$

[M]any reasons lead to the adoption by the Member States of different levels of standards . . . economic, social, cultural, or climatological conditions have a strong influence on the setting up of standards. The same is also true with regard to the regulatory philosophy which is followed by every country in relation to the protection of consumers' interests in safety. ${ }^{42}$

For example, in the control of drugs, national legislation among Member States varies greatly; where Ireland and Great Britain exercise only modest control of drugs by prohibiting the sale of any drug which is not of the quality and kind demanded by consumers, Denmark, France, and Germany exercise strict control by requiring actual proof of the drug's effectiveness

39. Coopers \& Lybrand, supra note $21, \S 4.1$.

40. Trubek, supra note 10 , at 108.

41. NORBERT REICH AND HaNS W. MiCKLITZ, CONSUMER LEgisLation IN THE EC COUNTRIES: A COMPARATIVE ANALYSIS 198 (1980). See also id. at 75-76.

42. Argiros, supra note 8, at 144. 
before it may be placed on the market. ${ }^{43}$ However, with the implementation of a common market and the subsequent free movement of goods, consumers throughout the Community can purchase products manufactured in other Member States which have different, and many times conflicting, product standards. If a nation refuses to distribute a Member State's products, albeit inferior in quality or safety, it obstructs the free movement of goods in violation of the EC Treaty and becomes subject to sanctions for the violation. Conversely, if a nation complies with the free movement of goods by allowing the sale to consumers of a good which fails to meet national health and safety specifications, consumers unknowingly may be faced with enhanced dangers in the marketplace. Without common standards and consumer protection laws throughout the Community, the common market would deprive the Member States of their ability to protect consumers. ${ }^{44}$ Consequently, "[i]t is imperative that consumer law in the EC countries be harmoni[s]ed with regard both to substance and to enforcement."45 And, consumer protection law centralized at the Community level may be the only effective form of regulation for the health and safety of consumers. ${ }^{46}$ To remedy the conflict between free trade and consumer protection, the $\mathrm{EC}$ has attempted to create a Community consumer policy that shields consumers from the dangers inherent in conflicting national laws.

\section{B. Community Consumer Protection Law}

Recognizing the inadequacy of national laws to protect consumers within a common market, the Community determined that, "the creation of a European Community with a common market necessitates a comprehensive and coherent policy at Community level in order to protect consumers." ${ }^{177}$ Because a principal objective delineated in the Treaty of Rome is "'the [c]onstant improvement of the living and working conditions of the [European] peoples,' the Heads of State indicated that consumer protection was a valid subject of community action ... ." 48 Moreover, two additional justifications exist for Community action to protect consumers:

[f]irstly, the single market is ... part of the creation of a

43. Reich \& Micklitz, supra note 41 , at 83.

44. Argiros, supra note 8, at 139.

45. Reich \& Micklitz, supra note 41 , at 198.

46. Argiros, supra note 8, at 139.

47. Id. at 140 .

48. Trubek, supra note 10 , at 106. 
'Citizens' Europe' in which the protection of the consumer is a vital cross-border issue requiring a common policy. Secondly, the primacy and direct applicability of Community legislation makes the European Union Institutions the only effective bodies to implement such a policy. ${ }^{49}$

Thus, while safeguarding the health of the European citizen, the Community must eliminate "[q]uantitative restrictions on imports and all measures having equivalent effect" ${ }^{\text {s0 }}$ which are not "justified on grounds of . . the protection of health and life of humans"s1 and which "constitute a means of arbitrary discrimination or a disguised restriction on trade between Member States." ${ }^{152}$ Consequently, the Community and its Member States may erect trade barriers only for the purpose of protecting the health and life of humans.

The principal objective of the Community's consumer policy has been to increase the overall level of protection afforded to consumers within the Community. ${ }^{53}$ Rather than eliminating all the differences in national consumer protection laws between Member States, the Community has emphasized the protection of the public from injury ${ }^{54}$ and the improvement of the general legal protection of consumers. ${ }^{\text {ss }}$ Therefore, over the past two decades, the Community has embarked upon the creation of a Community consumer policy through consumer protection legislation and through a developing body of case law in the Court of Justice of the European Communities.

\section{Community Consumer Protection Legislation}

In 1975, the EC adopted its first consumer protection program which enumerated the five basic rights of consumers: protection of economic interests; protection of health and safety; information and education; representation; and redress of grievances. ${ }^{56}$ Moreover, in 1985, the EC Commission issued mandates on completing the internal market which "[laid] down a programme and timetable for the abolition of barriers of all

49. Coopers \& Lybrand, supra note $21, \S 1$.

50. EC TREATY art. 30 (emphasis added).

51. EC TREATY art. 36.

52. Id.

53. Argiros, supra note 8 , at 140.

54. Thomas Trumpy, Consumer Protection and Product Liability: Europe and the EEC, 11 N.C.J. INT'L L. \& COM. REg. 321,334 (1986).

55. Argiros, supra note 8 , at 155.

56. Trubek, supra note 10 , at 106 . 
kinds in inter-state trade, the harmoni[s]ation of rules, the approximation of legislation ... [t $]$ o complete the internal market ... [and] provide[d] for removal of physical, technical and fiscal barriers." ${ }^{57}$ The EC further delineated the protection of consumer health and safety to be an urgent priority for the Community. ${ }^{58}$ This section describes the EC's progress in enhancing consumer protection through Community legislation.

Focusing on the harmonization of the various laws of Member States, the EC has developed "Community-wide general consumer safety legislation, which would not attempt to restrict local initiatives, but to coordinate and complement them." ${ }^{59}$ The EC also has emphasized the improvement of standardization procedures to reduce the technical barriers to trade erected from differences in national health and safety regulations. ${ }^{60}$ Because "[c]onflicting national laws ... constitute a clear barrier to intracommunity trade ... the EC has issued numerous directives which require Member States to bring national law into conformity with common standards." ${ }^{\text {61 }}$ In particular, the EC Commission ${ }^{62}$ has adopted mandatory framework directives that delineate essential minimum health and safety requirements for groups of products, including toys, certain medical devices, and machinery, before they can be sold in an EC Member State. ${ }^{63}$ Products which conform to the essential requirements specified in the directives are

57. Mathijsen, supra note 25, at 12-13.

58. Coopers \& Lybrand, supra note $21, \S 4.1$.

59. Argiros, supra note 8 , at 146.

60. EC Commentaries: The Free Movement of Goods § 1, Coopers \& Lybrand, Sept. 22, 1994, available in LEXIS, INTLAW Library, EURSCP File.

61. Trubek, supra note 10, at 106. An EC directive "shall be binding, as to the result to be achieved, upon each Member State to which it is addressed, but shall leave to the national authorities the choice of form and methods." EC TREATY art. 189.

62. The EC Commission "is responsible for the functioning and development of the common market and is the 'guardian of the Treaty,' i.e. makes sure everybody acts in accordance with the rules included therein." Mathijsen, supra note 25, at 52-53. See also EC TREATY art. 155 ("In order to ensure the proper functioning and development of the common market, the Commission shall: ensure that the provisions of this Treaty and the measures taken by the institutions pursuant thereto are applied; formulate recommendations or deliver opinions on matters dealt with in this Treaty, if it expressly so provides or if the Commission considers it necessary; have its own power of decision and participate in the shaping of measures taken by the Council and by the Assembly in the manner provided for in this Treaty; exercise the powers conferred on it by the Council for the implementation of the rules laid down by the latter.").

63. Coopers \& Lybrand, supra note 21, § 4.1. See also Coopers \& Lybrand, supra note $6, \S 5.1$ (discussing adoption by Council in 1985 of the "New Approach to Technical Harmonisation and Standards" which specifies essential requirements for consumer products that must be satisfied before the products can be sold within the Community). 
guaranteed free movement within the Community. ${ }^{64}$ For example, in 1988, the Community adopted a directive for the safety of toys that established essential requirements relating to the physical properties, flammability, and hygiene of toys to be distributed within the Community. ${ }^{65}$ Pursuant to the directive, "[a]n approved body in each Member State examines the toy . . . for the essential requirements ... and, if satisfied, will issue an EC conformity stamp, which will ensure free circulation." ${ }^{66}$ Moreover, the General Product Safety Directive, ${ }^{67}$ which will become effective in 1994 and which requires all products distributed within the Community to be safe, ${ }^{68}$ constitutes the EC's most far-reaching measure towards advancing product safety within the Community. Specifically, the directive requires Member States to take "'all necessary measures' to ensure that products . . - '[do] not present, in particular in respect of its design, composition, execution, functioning, wrapping, conditions of assembly, maintenance or disposal, instructions for handling and use, or any other of its properties, an unacceptable risk, for the safety and health of persons, either directly or indirectly." 69 The directive further "instructs each member nation to establish a government authority to monitor product safety and ensure compliance by manufacturers and distributors." ${ }^{\text {"0 }}$ Finally, each Member State has the power to cease the importation of a product which it genuinely believes poses a threat to the health and safety of its citizens by informing the Commission and by following established procedures. ${ }^{71}$ However, as required by the EC Treaty, "[t]he Commission must be satisfied that the import restriction is not an attempt to put up a disguised barrier to trade..$^{172}$ Accordingly, the EC facilitates the removal of hazardous products from the common market without entirely compromising the Member States' commitment to promote the free movement of goods.

Through the issuance of directives to Member States, the Community has sought to eliminate the barriers to trade emanating from the disparities between national health and safety requirements and to establish a uniform level of safety within the common market which affords consumers a high level of protection. ${ }^{73}$ Additionally, to ensure that Community consumer

64. Coopers \& Lybrand, supra note $6, \$ 5.2$.

65. Council Directive 88/378, 1988 O.J. (L187).

66. Coopers \& Lybrand, supra note $21, \$ 9$.

67. Council Directive 89/162, 1992 O.J. (L228).

68. Julie Gannon Shoop, European Community Adopts Product Hazard Reporting Requirements, TRIAL, June 1992, at 91.

69. Id. at 92.

70. Id.

71. Coopers \& Lybrand, supra note $21, \S 4.2$.

72. Id. § 4.1.

73. Id. 
protection legislation is transposed into national law, the Community adopted a three-year New Action Plan on July 28, 1993 which further emphasizes the continuous development of consumer protection legislation within the Community. ${ }^{74}$

\section{The Court of Justice of the European Communities}

While Community legislation is designed to balance the aims of establishing the free movement of goods with national interests in regulating the health and safety of consumers, the Court of Justice of the European Communities (Court of Justice) has become the "umpire governing this balance. ${ }^{75}$ The Court of Justice must "ensure that in the interpretation and application of this Treaty the law is observed." ${ }^{176}$ The Court of Justice interprets and formulates the law by referring to the objectives of the Community and by ensuring that the law furthers the accomplishment of these objectives. ${ }^{77}$ Therefore, in the area of consumer policy, the Court of Justice must ensure that the free movement of goods is not hindered by national health and safety regulations, while enabling the Community to attain its goal of affording consumers a high level of protection. ${ }^{78}$ Thus, the Court of Justice has attempted to harmonize existing differences in national consumer health and safety legislation based on Article 100 of the EC Treaty and has not permitted the aim of free intracommunity trade to prevail over the aim of consumer protection. ${ }^{79}$ This section illustrates the court's attempts at balancing Community consumer protection with the free movement of goods.

\section{A. Towards the Free Movement of Goods}

In the landmark case of Rewe-Zentral $A G$ v. Bundesmonopol-

74. Id. $\$ 2$.

75. Clark, supra note 29 , at 779.

76. EC TREATY art. 164.

77. Mathijsen, supra note 25 , at 69.

78. As provided in the EC Treaty art. 2, the European Community shall establish a common market. And, as added by art. 100A of the Single European Act, consumers are to be granted a "high level of protection." EC TREATY art. 100A.

79. L. KRAMER, EEC CONSUMER LAw 8 (1986). See also EC TREATY art. 100 (declaring that, "[t]he Council shall, acting unanimously on a proposal from the Commission, issue directives for the approximation of such provisions laid down by law, regulation or administrative action in Member States as directly affect the establishment or functioning of the common market."). 
verwaltung, otherwise known as Cassis de Dijon, ${ }^{80}$ the Court of Justice determined that a national regulation on alcoholic beverages that restricted the free movement of goods but did not serve to protect the public health was barred by the EC Treaty. After German authorities refused to allow the importation of Cassis de Dijon, a French liqueur which contained less than twenty percent alcohol and was freely marketed in France, the importer alleged that the German law requiring a minimum alcohol content of twenty-five percent constituted an obstruction to the free movement of goods in violation of the EC Treaty. The court determined that, "the unilateral requirements imposed by the rules of a Member State of a minimum alcohol content for the purposes of the sale of alcoholic beverages constitute an obstacle to trade which is incompatible with the provisions of Article 30 of the Treaty. ${ }^{181}$ Because Germany's law restricted free trade and did not further the health and safety of consumers, the law could not survive attack.

Similarly, in Commission v. Republic of Greece ${ }^{82}$ and Commission v. Germany, ${ }^{83}$ the Court of Justice invalidated Greek and German legislation restricting the importation of beer for purposes other than the protection of consumer health and safety. Specifically, in Commission v. Republic of Greece, the Court of Justice invalidated a Greek national law that mandated that importers of foreign beer first demonstrate that the imported beer was made from barley malt and met a minimum density requirement; products which failed to meet these requirements could not be sold as beer in Greece. Although the Greek government contended that the law was justified to protect the public health, the Court of Justice determined that, "a prima facie justification on grounds of health protection for such measures has not been made out .... ${ }^{\text {"84 }}$ Although

it is for the member states, in the absence of community-wide harmonization, to decide what degree of protection of health and life of humans they intend to ensure, having regard however to the requirements of the free movement of goods within the

80. Case 120/78, Rewe-Zentral AG v. Bundesmonopolverwaltung, 1979 E.C.R. 649, available in LEXIS, INTLAW Library, ECCASE File.

81. Id. (referring to Article 30 of the EC Treaty which provides, "[q]uantitative restrictions on imports and all measures having equivalent effect shall, without prejudice . . . be prohibited between Member States.").

82. Case 176/84, Commission v. Republic of Greece, 1987 E.C.R. 1193, available in LEXIS, INTLAW Library, ECCASE File.

83. Case 178/84, Commission v. Germany, 1987 E.C.R. 1227, available in LEXIS, INTLAW Library, ECCASE File.

84. Case 176/84, Commission v. Republic of Greece, 1987 E.C.R. 1193, available in LEXIS, INTLAW Library, ECCASE File. 
Community ... such prohibitions or restrictions on imports from other member states on the ground of public health must not constitute a means of arbitrary discrimination or a disguised restriction on trade between member states. ${ }^{85}$

Because the Greek national law could not be justified as necessary to protect the public health, Greece's refusal to permit the importation of beer from other Member States violated the EC Treaty. Likewise, in Commission v. Germany, the Court of Justice determined that a German law which required imported beer to satisfy a beer purity standard constituted a barrier to the free movement of goods in violation of the EC Treaty. ${ }^{86}$ These landmark cases illustrate that, in the absence of a genuine contribution to the health and safety of consumers, a national law which inhibits the free movement of goods will not withstand attack in the Court of Justice.

\section{B. Towards the Protection of Consumers}

Although it recognized the importance of the free movement of goods, the Court of Justice determined that, "obstacles to movement within the Community resulting from disparities between the national laws ... must be accepted in so far as those provisions may be recognized as being necessary in order to satisfy mandatory requirements relating in particular to ... the protection of public health . .. and the defence [sic] of the consumer." ${ }^{187}$ Therefore, the Court of Justice tolerates those national laws which, although restrictive of free trade, are designed to protect consumers from exaggerated dangers. ${ }^{88}$ For example, in Mirepoix, ${ }^{89}$ the Court of Justice indicated a greater willingness to permit Member States to restrict imports of products which reveal traces of pesticides. ${ }^{90}$ Similarly, in Sandoz, the Court of Justice reaffirmed the ability of Member States to restrict the importation of foodstuffs containing vitamins with an uncertain

85. Id.

86. EC Treaty art. 30 prohibits "[q]uantitative restrictions on imports and all measures having equivalent effect." EC TREATY art. 30.

87. Case 120/78, Rewe-Zentral AG v. Bundesmonopolverwaltung, 1979 E.C.R. 649, (emphasis added), available in LEXIS, INTLAW Library, ECCASE File.

88. Thomas van Rijn, A Review of the Case Law of the Court of Justice on Articles 30 to 36 EEC in 1986 and 1987, 25 COMMON MKT. L. REV. 593, 598 (1988).

89. Case 54/85, Ministere Public v. Xavier Mirepoix, 1986 E.C.R. 1067, available in LEXIS, INTLAW Library, ECCASE File.

90. Van Rijn, supra note 88. 
degree of harmfulness. ${ }^{91}$ However, the power of Member States to restrict imports through national measures is not without constraints; ${ }^{92}$ although Member States have the authority to adopt national legislation to protect the public health in the absence of Community legislation, they must "restrict themselves to what is actually necessary to secure the protection of the public health." ${ }^{93}$ By enabling Member States to protect public health, the Court of Justice attains the desired balance between free trade and consumer protection.

\section{Towards the Protection of Consumers in a Single European Market}

In attempting to balance the free movement of goods with the necessary protection of consumers in a common market, the Court of Justice has demonstrated that national regulations which are designed to protect consumers will be viewed in light of the Community's goal to establish a common market with the free movement of goods between nations. ${ }^{94}$ Therefore, Member States can adopt necessary national health and safety legislation in the absence of Community regulation; however, the legislation must be non-discriminatory in nature and no more restrictive of the free movement of goods than necessary to protect the public health and safety. ${ }^{95}$ By facilitating the protection of consumers within the common market, the Court of Justice balances the two fundamental goals of the Community: the free movement of goods and a uniformly high level of protection for consumers.

In its endeavor to complete an internal market with the free movement of goods, the European Community has encountered considerable difficulty in balancing the aims of free trade and the growing desire to protect consumers from enhanced dangers in a common market. As the need for a Community-wide consumer protection program to harmonize the varying laws of Member States intensified, the Community's development of consumer protection legislation and Court of Justice case law has been instrumental in synthesizing the often conflicting objectives of consumer protection and free trade. The movement of consumer protection within the

91. Case 174/82, Criminal Proceedings against Sandoz BV, 1983 E.C.R. 2445, available in LEXIS, INTLAW Library, ECCASE File.

92. Case 176/84, Commission v. Republic of Greece, 1987 E.C.R. 1193, available in LEXIS, INTLAW Library, ECCASE File.

93. Case 178/84, Commission v. Germany, 1987 E.C.R. 1227, available in LEXIS, INTLAW Library, ECCASE File.

94. Goyens, supra note 32 , at 71 .

95. Case 178/84, Commission v. Germany, 1987 E.C.R. 1227, available in LEXIS, INTLAW Library, ECCASE File. 
European Community illustrates the inherent conflict between free trade and consumer protection and suggests potential solutions to this conflict for other free trading blocs such as North America.

\section{The North American Free Trade Agreement AND CONSUMER PROTECTION}

With the affirmative vote of the U.S. House of Representatives on November 17, 1993, the North American Free Trade Agreement (NAFTA) between Mexico, Canada, and the United States became the first free trade agreement to be reached between an emerging economy and developed countries. ${ }^{96}$ NAFTA will create a free trade zone that stretches from the Yukon to the Yucatan; ${ }^{97}$ it will encompass over 360 million consumers and account for over six trillion dollars in annual output. ${ }^{98}$ In fact, the North American common market created under NAFTA will be larger than that of the European Community. ${ }^{99}$

Pursuant to NAFTA, the United States, Mexico, and Canada have "resolved to ... . create an expanded and secure market for the goods and services produced in their territories; reduce distortions to trade; establish clear and mutually advantageous rules governing their trade."100 Specifically, over a fifteen year period, the nations will "eliminate barriers to trade in, and facilitate the cross border movement of, goods and services between the territories of the Parties."101 To accomplish these goals, Mexico's tariffs on American and Canadian imports, which are approximately two and one-half times higher than in the United States, will

96. Jill Dutt, Trading Opinions Making Sense of all the Hype over NAFTA, NEWSDAY, Nov. 7, 1993, at 5 .

97. Judith $\mathrm{H}$. Bello and Alan F. Holmer, The NAFTA: Its Overarching Implications, 27 THE INTERNATIONAL LAWYER 3, 590 (1993).

98. White House Fact Sheet: The North American Free Trade Agreement, 28 WEEKLY COMP. PRES. DOC. 1424 (Aug. 12, 1992).

99. Jesse Jackson, Free Trade: A Fast One on the Fast Track, Los ANGELES TIMES, Apr. 15, 1991, at 5.

100. NAFTA, supra note $17, \mathrm{pmbl}$.

101. NAFTA, supra note 17, art. 102. See also Dutt, supra note 96 ("Tariffs and quotas would be eliminated immediately on many manufactured and agricultural products, within 10 years on most others and within 15 on all eligible products."). Additionally, eighteen percent of U.S. exports to Mexico are now duty-free; by the year $2009,100 \%$ of U.S. exports to Mexico will be duty-free. Additionally, $45 \%$ of Mexican exports to the U.S. are now duty-free; by the year $2009,100 \%$ of Mexican exports to the U.S. will be duty-free. Id. 
be eliminated, ${ }^{102}$ and other trade barriers will be reduced to facilitate the free movement of goods in North America. Additionally, through NAFTA, the United States, Mexico, and Canada will seek "to improve working conditions and living standards in their respective territories" ${ }^{\prime 103}$ and to "preserve their flexibility to safeguard the public welfare."104

During the NAFTA debate in the United States, many consumer advocate groups vehemently opposed the agreement on grounds that the disparate level of protection afforded to consumers in Mexico would jeopardize the protection afforded to American consumers in a North American common market. Opponents contended that NAFTA will enable Mexican goods which are inferior in safety and quality to be sold within the market in the United States, thereby jeopardizing the health of American consumers. Furthermore, consumer advocates feared that consumer protection laws in the United States which regulate the sale of Mexican products in the United States' market would be vulnerable to attack as nontariff barriers to trade in violation of NAFTA. This section explores the opposition to NAFTA launched by consumer groups, discusses the validity of the opposition in light of consumer protection in Mexico, and addresses NAFTA's adequacy in safeguarding consumer protection while facilitating free trade in North America.

\section{A. Opposition to NAFTA}

Various groups in the United States including farm, labor, environmental and consumer groups fought actively to obstruct the passage of NAFTA. ${ }^{105}$ In particular, consumer groups such as Public Citizen and the Citizens Trade Campaign contended that NAFTA is "a bad agreement for consumers." 106 Specifically, they argued that NAFTA will harm consumers in two ways: first, it will allow inferior and unsafe Mexican products to be sold freely in the United States; and, second, it will enable Mexico to challenge consumer protection laws in the United States as nontariff barriers to trade which must be eliminated in accordance with the free trade agreement. Therefore, opponents contended that free trade with Mexico will have dramatic effects on consumer protection laws in the

102. Dutt, supra note 96.

103. NAFTA, supra note 17 , pmbl.

104. Id.

105. David R. Sands, Trade Negotiators have a Full Plate; "Kitchen Sinkers" Pile on Side Issues, THE WASHngTON TIMES, June 13, 1993, at A12.

106. Federal News Service, supra note 5. 


\section{United States. ${ }^{107}$}

Among the effects postulated by consumer advocates was first that the opening of borders between Mexico and the United States will facilitate the sale in the United States of certain Mexican products which were produced in accordance with less stringent health and safety standards and which are hazardous to consumers. For example, because many agricultural practices and pesticides that are illegal in the United States are used openly in Mexico, many consumers fear that food exported to the United States could be adulterated and unsafe for consumption. ${ }^{108}$ "That means [consumers] could unwittingly buy a tomato at the store that's full of toxins." 109 And, to refuse imports of Mexican food or other goods "is to restrain free trade, a violation of NAFTA."110 Second, many opponents argued that NAFTA will enable domestic consumer health and safety standards to be challenged by trading partners as non-tariff barriers to trade which obstruct the free movement of goods. ${ }^{\prime \prime \prime}$ Because health and safety standards in the United States are comparatively higher than in other nations, critics contend that standards in the United States necessarily will be diminished by the harmonization required to open borders. ${ }^{12}$ Moreover, they argue that the agreement "says quite bluntly that any legislation that interferes with free trade violates the agreement. That means that all the . . . consumer protection laws enacted in our country are subject to being overruled by NAFTA in order to facilitate the free flow of trade between our countries." ${ }^{113}$ Finally, opponents argued that the interests in establishing

107. Sands, supra note 105.

108. Bill Evans, NAFTA is a Disaster, The SAN FranCisCo ChroniCle, Apr. 1, 1993, at $\mathrm{A} 20$.

109. Dutt, supra note 96.

110. Evans, supra note 108. See also Marian Burros, Eating Well, THE NEW YORK TimES, Apr. 28, 1993, at C4 (statement of Lori Wallach, a lawyer for Public Citizen) ("Country X wants to sell its applesauce to the United States. When the applesauce arrives, it is sampled for pesticide residues, and the levels of pesticide are well above what United States regulations allow, although the levels are in accordance with the standards adopted by the free-trade [sic] agreements. The United States rejects the applesauce, but Country $\mathrm{X}$ contends that the rejection is a barrier to free trade. Country $X$ goes to a tribunal set up under GATT or NAFTA and asks the tribunal to determine whether the American action is a barrier to free trade. If the tribunal agrees with Country $X$, the United States has two options: it can change its law governing the amount of pesticides permitted in the applesauce, or it can pay Country $\mathrm{X}$ for its lost trade.").

111. Claybrook, supra note 18.

112. Id. See also Goldman, The Legal Effect of Trade Agreements on Domestic Health and Environmental Regulation, 7 J. ENVTL L. \& LITTG. 11 (1992) ("Harmonization of U.S. and Mexican health and environmental laws is of particular concern because Mexico's laws are much weaker than U.S. standards.").

113. Evans, supra note 108. 
free trade will prevail over concerns for the health and safety of consumers because "rules are so skewed in favor of free trade."114 Thus, with the implementation of free trade in North America, critics contend that the protection of consumers will be subordinated to the goal of the free movement of goods in North America. To determine the legitimacy of the consumer groups' opposition to NAFTA and the feasibility of implementing free trade while maintaining protection for consumers in North America, Mexico's consumer protection laws and their effectiveness must be examined.

\section{B. Consumer Protection in Mexico}

Prior to the enactment of Mexico's Federal Consumer Protection Act (FCPA) in 1975, ${ }^{115}$ protection for Mexican consumers was virtually nonexistent. ${ }^{116}$ No consumer protection laws existed in Mexico, and traditional means of legal redress for consumers were too expensive, slow and complicated. ${ }^{117}$ However, with an expanding base of consumers and with Mexico's endeavor toward industrialization, the need for consumer protection became increasingly apparent. ${ }^{118}$ The FCPA was created to provide consumers with "an important avenue towards social justice."119 However, nearly twenty years after its enactment, the protection actually received by Mexican consumers is questionable. Many observers contend that, despite the laws on Mexico's books, enforcement of these laws is inadequate. ${ }^{120}$ This section examines the FCPA and its effectiveness in affording consumers adequate protection in the marketplace.

\section{Federal Consumer Protection Act of 1975}

Mexican consumer law originated with the enactment of the Federal

114. Dutt, supra note 96.

115. Ley Federal de Protección al Consumidor D.O., December 22, 1975 [hereinafter FCPA]. The FCPA became effective on February 5, 1976.

116. Jorge A. Vargas, An Overview of Consumer Transactions Law in Mexico: Substantive and Procedural Aspects, 10 N.Y.L. SCH. J. INT'L \& COMP. L. 345, 347 (1989).

117. Id. at 348.

118. Id. at 347-48.

119. Mexico Faces a Year of Official Austerity, LATIN AMERICAN NEWSLETTER, Jan. 2,1976 , at 2.

120. Hearing of the Employment and Housing Subcommittee of the House Government Operations Committee: NAFTA's Effect on Labor Issues, Federal News Service, Oct. 7, 1993, available in LEXIS, INTLAW Library, NAFTA File. 
Consumer Protection Act in 1975. The FCPA was created to reflect eight guiding legal principles for the protection of consumers which continue to influence consumer legislation in Mexico today: 1) consumer protection norms are legally binding; 2) the relationship between consumers and merchants is based on truthfulness; 3 ) contracts must be drafted clearly and precisely; 4) warranties on goods and services are legally enforceable; 5) maximum interest rates in credit transactions should be established by public authorities; 6) consumers have the right to judicially alter unilateral clauses in adhesion contracts; 7) consumers can employ administrative procedures to alter unfair treatment or misleading practices of merchants; and 8) advertising and sales should be regulated by public authorities. ${ }^{121}$ The FCPA regulates a wide variety of consumer transactions ${ }^{122}$ including advertising, warranties, consumer credit transactions, services, door to door sales, liability for non-performance, warnings and instructions for dangerous goods. ${ }^{123}$ All individuals and entities who provide services or make or distribute goods are subject to the FCPA; ${ }^{124}$ violations of the minimum standards for products and services delineated in the FCPA are sanctioned by the Office of the Federal Attorney General for Consumer Affairs. ${ }^{125}$ Additionally, all enterprises in Mexico must register with the Ministry of Health and Welfare which "supervise[s] conditions of sanitation; the production, packaging, advertising and sale of foods, drinks, medicines and related products; and public health." ${ }^{126}$ However, despite the protection afforded by these regulations, "[a]reas in which more detailed and technical regulations will be required in Mexico include food products, electric domestic appliances ... pharmaceutical products . . ."127 Furthermore, the actual effectiveness of the FCPA in regulating consumer health and safety and in providing protection to consumers has been challenged.

\section{Effectiveness of Consumer Protection in Mexico}

The protection actually afforded to consumers in Mexico is oft-debated. The inadequate enforcement of consumer laws in Mexico is viewed as a principal downfall of Mexico's consumer protection program. "Even where Mexico has strong standards in place, it has inadequate enforcement

121. Vargas, supra note 116, at 351-53.

122. Id. at 362.

123. FCPA, supra note 115.

124. Price Waterhouse, DoIng Business IN MeXico 62 (1991).

125. Vargas, supra note 116, at 361-62.

126. Price Waterhouse, DoINg Business IN MEXico 33-34 (1984).

127. Vargas, supra note 116 , at 382. 
capabilities."128 Similarly, "the rules can change in a minute in Mexico . . . [b]ut people have to find things out for themselves." 129 For example, one firm "recently had a shipment held up at the border for weeks, when the Mexican government suddenly began enforcing a previously ignored labeling law."130 The lack of enforcement and predictability of the laws in Mexico tends to lessen consumer protection and to facilitate the sale of many products which endanger the health and safety of consumers. For example, Picarindo brand candy, manufactured in Mexico and exported to the United States, was found to contain high levels of potentially dangerous lead, both within the candy and its packaging, and prompted an immediate warning to California consumers to avoid consuming the candy before it was recalled from the marketplace. ${ }^{131}$ Other examples include breaded steak sandwiches sold in Mexico that are actually made of paper, brands of tequila which are largely composed of water, underweight tortillas that cause a loss of $\$ 370,000$ to Mexican consumers for tortillas they never eat, and parrots that appeared to speak in the pet shop only because the shop owner was a ventriloquist. ${ }^{132}$ Further, many dangerous products are sold to unknowing consumers without even a warning; to illustrate, an educational brochure which accompanied a child's toy chemistry set neglected to inform consumers that "the set packs enough power to blow a kid to bits." ${ }^{133}$ The Director of the Mexican Association of Studies for the Defense of the Consumer explains that, "'Mexican consumers are so used to being cheated that they don't complain enough.'"'134 As a consumer activist for sixteen years, "[h]e has spoken out against unscrupulous sausage makers, underweight cookie packets, overweight policemen, contaminated ice cubes and bribe-taking bureaucrats." 135 And, "there are plenty of things he hasn't gotten to yet."136 Additionally, for those consumers who do complain, the process of filing a complaint with Mexico's consumer protection agency is time-consuming and frustrating; "[i]t can involve up to

128. Goldman, supra note 112.

129. Matt Moffett, U.S. Firms Yell Olé to Future in Mexico, THE WALL STREET JOURNAL, March 8, 1993, at B1.

130. Id.

131. Californians Warned Against Mexican Candy, JOURNAL OF COMMERCE, May 7 , 1993, at $4 A$.

132. Matt Moffett, Mexican Consumers Have a Stout Friend in Arturo Lomeli. . . They Need One - To Uncover Bad Tequila, Mute Parrots, and Meat Made of Paper, THE WALL STREET JOURNAL, Jan. 18, 1988, at 1.

133. Id. at 7.

134. Id. at 1 .

135. Id.

136. Id. 
two days of standing in line [and] filling out forms in triplicate." ${ }^{137}$ Thus, despite the FCPA, it appears that little progress has been made in protecting consumers in Mexico. ${ }^{138}$ Consequently, to ensure the protection of consumers within the North American common market, it is essential that NAFTA provide a means of safeguarding consumers despite the disparate level of consumer protection among the North American trading partners.

\section{Consumer Protection under NAFTA}

The primary goal of NAFTA is the establishment of a North American common market. ${ }^{139}$ A second fundamental goal of the agreement, however, is to "improve working conditions and living standards in [the] respective territories" and to "preserve their flexibility to safeguard the public welfare." 140 Thus, as barriers to trade are eradicated, the health and safety of the public remains a prominent concern. Accordingly, NAFTA empowers the United States, Mexico, and Canada to establish a level of protection deemed necessary to protect the public. Specifically, NAFTA provides that, "each Party may, in pursuing its legitimate objectives of safety or the protection of human, animal or plant life or health, the environment or consumers, establish the level of protection that it considers appropriate."141 However, this power must not be exercised to inhibit the establishment of free trade. Rather, the nations must

avoid arbitrary or unjustifiable distinctions between similar goods or services in the level of protection it considers appropriate, where the distinctions: a) result in arbitrary or unjustifiable discrimination against goods or service providers of another Party; b) constitute a disguised restriction on trade between the Parties; or c) discriminate between similar goods or services for the same use under the same conditions that pose the same level of risk and provide similar benefits. ${ }^{142}$

Consequently, each nation has the right to establish regulations which are non-discriminatory in nature and essential to the public health and to refuse

137. Tod Robberson, Mexico's Hang-Up, ThE WASHINGTON POST, May 17, 1993, at A16.

138. Moffett, supra note 132.

139. NAFTA, supra note 17.

140. Id. pmbl.

141. Id. art. 904(2).

142. Id. art. $907(2)$. 
the importation of goods which fail to comply with health and safety standards. ${ }^{143}$ To illustrate, NAFTA stipulates that food entering the United States must comply with pesticide standards set in the United States; ${ }^{144}$ a failure to comply with these standards, which are applied both to domestic and to foreign products, enables the United States to refuse the importation of the food product. Moreover, to facilitate free trade and to enhance the safety and protection of consumers within the North American market, NAFTA mandates the joint development of harmonized standards for goods and services. ${ }^{145}$ The Committee on Standards-Related Measures, composed of representatives of each nation, will initiate the harmonization of standards; however, the Committee is authorized to develop subcommittees dealing with the standardization of consumer information, labeling, packaging, product approval and product surveillance programs and the overall facilitation of consumer protection. ${ }^{146}$ Consequently, by empowering the United States, Mexico, and Canada to take the necessary measures to protect the public health while requiring the development of harmonized regulations, NAFTA does not sacrifice consumer welfare to the establishment of free trade within North America. Rather, the nations must collaborate to harmonize health and safety standards and to afford consumers a commensurate level of protection throughout North America. Given the disparate level of protection currently afforded to consumers in North America, this is a formidable task for which the experience of the European Community provides a viable model.

143. Testimony of Charles E. Roh, Jr., Assistant U.S. Trade Representativefor North American Affairs, Office of the United States Trade Representative before the Committee on Science, Space and Technology, U.S. House of Representatives, Sept. 30, 1992, available in LEXIS, INTLAW Library, NAFTA File. See also Report of the Industry Sector Advisory Committee for Trade in Consumer Goods on the North American Free Trade Agreement, Sept., 1992, available in LEXIS, INTLAW Library, NAFTA File.

144. Dutt, supra note 96.

145. NAFTA, supra note 17, art. 906(1) ("Recognizing the crucial role of standardsrelated measures in achieving legitimate objectives, the Parties shall, in accordance with this Chapter, work jointly to enhance the level of safety and of protection of human . . . life and health . . . and consumers."). See also id. art. 906(2) ("Without reducing the level of safety or of protection of human ... life or health ... or consumers, without prejudice to the rights of any Party under this Chapter, and taking into account international standardization activities, the Parties shall, to the greatest extent practicable, make compatible their respective standards-related measures, so as to facilitate trade in a good or service between the Parties.").

146. Id. art. 913. 


\section{THE European COMmunity as a Paradigm for North AMERICA}

As the United States, Canada, and Mexico endeavor to create a single North American market, varying consumer protection laws will hinder the establishment of free trade. A reduction in the barriers to trade among trading partners is crucial to free trade; however, a reduction in the level of protection afforded to consumers in a common market is not desirable, particularly where an enhancement in the living standards of North Americans is a fundamental objective of the trading relationship. Like the European Community, North America must attain a balance between free trade and the protection of the health and safety of consumers. Consequently, the movement of consumer protection that accompanied the European Community's implementation of cross-border trade demonstrates a formidable challenge to the realization of a North American free trading zone: the harmonization of consumer protection laws.

The movement of consumer protection in the EC provides several useful lessons for the nations of North America as they embark upon the creation of a North American free trading zone. First, the EC experience demonstrates that national consumer protection laws may not be effective in the supranational or international environment ${ }^{147}$ where trading partners with varying national laws engage in cross-border trade. In fact, even local, regional, or national measures may not suffice to afford consumers adequate protection where trade occurs on an international level. ${ }^{148}$ Therefore, "although using trade policy to change another country's pollution standards or food safety controls greatly complicates trade negotiations, 'nevertheless the reality is that global companies competing in global markets ultimately require global rules." 149 Thus, as products cross national boundaries to be sold in foreign markets, consumer protection laws also must be able to transgress national boundaries so that multilateral trade does not diminish the protection afforded to consumers in expanding marketplaces. Second, the EC experience illustrates that the integration of the economies of trading partners through a free trade agreement also demands the integration of social policies among trading partners, including consumer protection laws. ${ }^{150}$ Therefore, the implementation of free trade mandates a reconciliation between the consumer protection policies of the trading partners in order to protect consumers within the free trading bloc. Finally,

147. Trubek, supra note 10 , at 111 .

148. GEOFFREY WOODROFFE, CONSUMER LAW IN THE EEC 37 (1984).

149. Sands, supra note 105 (quoting Geza Feketekuty, a senior policy adviser for the U.S. Trade Representatives Office).

150. Jorge G. Castaneda, Perspectives on Free Trade - Canada, Mexico: a Kinship Evolves, Los ANGELES TIMES, Mar. 3, 1991, at 7. 
the EC experience indicates that the concurrent implementation of free trade and the maintenance of consumer protection is a formidable task. The development of product standards within the EC has been a long and complex process which has been hindered by the varying needs, expectations, manufacturing sophistication levels and traditions in the twelve Member States. ${ }^{151}$ Moreover, despite the lack of development in several EC Member States such as Spain, Portugal, and Greece, the EC has not allowed their underdeveloped consumer protection laws to compromise the desired level of protection for consumers within the Community. In fact, the more developed Member States in the EC "have no intention of letting the three new Southern members, Portugal, Greece, and Spain, export goods like toys, made without any appreciable safety standards, to other markets within the [EC]."152 Rather, the Community has sought to elevate the standards of all nations to afford a uniform and desirable level of protection to consumers throughout the Community.

Similarly, as the first free trade agreement to be reached between an emerging economy and two developed economies, the implementation of NAFTA will pose substantial challenges to the United States, Mexico, and Canada as these nations attempt to synthesize their consumer protection laws and ensure the establishment of a North American common market in which consumers are protected from the hazards of consuming dangerous products. Thus, the standards to be developed under NAFTA will necessarily require a great deal of collaboration and effort by trading partners. The European experience provides a useful model for North America as it strives to create a North American free trade zone in which consumers receive a satisfactory level of protection.

\section{CONCLUSION}

Reconciling the conflicting goals of free trade and consumer protection is a formidable task for countries who engage in free trade agreements. While seeking to eradicate barriers to the free flow of goods between nations, many free trading nations also wish to obstruct the flow of goods which endanger public health and safety through national product health and safety standards. In this light, consumer protection laws may often be challenged as trade barriers which contravene free trade agreements despite their value in safeguarding the public health. Thus, the harmonization and standardization of consumer protection laws is essential to the successful

151. Coopers \& Lybrand, supra note $21, \S 4.1$.

152. Trumpy, supra note 54 , at 338 . 
implementation of a free trade agreement.

In the implementation of a single European market, the European Community has found the harmonization of conflicting national consumer protection laws of its twelve Member States to be vital in facilitating free trade while simultaneously affording consumers adequate protection in a common market. Through the implementation of consumer protection legislation and a developing body of case law, the Community has made substantial progress in harmonizing national laws and in improving the protection of consumers in an expanding marketplace. Similarly, with the passage of NAFTA, the United States, Mexico, and Canada will embark upon a comparable process of creating a single North American market with the free movement of goods across national boundaries. And, although NAFTA empowers the United States, Mexico, and Canada to act for the public welfare and mandates the harmonization of product standards among the North American trading partners, maintaining a balance between the goals of free trade and the protection of consumers is an arduous task. Although consumer groups have a legitimate concern about the protection of North American consumers due to the inferior level of protection afforded to consumers in Mexico, the EC experience demonstrates that this obstacle can be overcome through collaboration and consideration for the rights of consumers in the implementation of free trade. Therefore, the EC experience in balancing the interests of free trade with the interests of consumer protection in a common market serves as a useful paradigm for North America as it embarks upon the implementation of NAFTA.

Paulee A. Coughlin

* J.D. Candidate, 1995, Indiana University School of Law-Indianapolis; M.B.A., Vanderbilt University, Owen Graduate School of Management; B.A., Vanderbilt University. 
